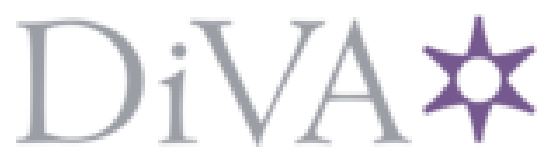

http://www.diva-portal.org

\title{
Postprint
}

This is the accepted version of a paper published in The Pacific Review. This paper has been peer-reviewed but does not include the final publisher proof-corrections or journal pagination.

Citation for the original published paper (version of record):

Bjarnegård, E., Melander, E. (2017)

Pacific Men: how the feminist gap explains hostility

The Pacific Review, 30(4): 478-493

https://doi.org/10.108o/o9512748.2016.1264456

Access to the published version may require subscription.

N.B. When citing this work, cite the original published paper.

Permanent link to this version:

http://urn.kb.se/resolve?urn=urn:nbn:se:uu:diva-314947 
This is an Author's Accepted Manuscript of an article published in Pacific Review on January 18,

available online: http://www.tandfonline.com/doi/full/10.1080/09512748.2016.1264456

How to cite this article: Bjarnegård, Elin and Erik Melander. "Pacific Men: How Attitudes to Gender Equality Explain Hostility". Pacific Review. (Forthcoming in a printed issue)

\section{Pacific Men:}

\section{How the Feminist Gap Explains Hostility}

\section{Elin Bjarnegård*}

Associate Professor, Department of Government

*Corresponding Author Elin.Bjarnegard@ statsvet.uu.se

\section{Erik Melander}

Professor, Department of Peace and Conflict Research

Revised version submitted November 8, 2016

Word count: 7384 


\section{Abstract:}

The gender gap in attitudes to foreign policy is well established in public opinion literature. Studies have repeatedly reported that women tend to be more peaceful and less militaristic than men. This article reexamines attitudes of individuals in relation to foreign policy and pits the gender gap against the largely forgotten feminist gap. We argue that the individual-level relationship between gender equality attitudes on the one hand, and tolerance and benevolence on the other, is under-researched, but also that key contributions about the effects of feminism have been mostly ignored in research on the gender gap in public opinion. We return to the notion that there is a causal relationship between gender equality attitudes on the one hand, and peaceful attitudes on the other, and that this feminist gap also exists among men. In a series of novel empirical tests, we demonstrate that the attitudes to gender equality, not the biological sex of the individual, explain the attitudes towards other nationalities and religious groups. Using individual-level survey data from five countries around the Pacific: China, Indonesia, Japan, South Korea, and the United States of America, we show that both men and women who reject gender equality are much more hostile both to other nations and to minorities in their own country. 


\section{Biographical notes:}

Elin Bjarnegård (Sweden) is a Senior Lecturer and Associate Professor at the Department of Government at Uppsala University, Sweden. She is a core group member of the East Asian Peace Program. Her research interests are within the field of comparative politics with a particular focus on gender, masculinities, conflict, political parties, and informal institutions. Her publications have appeared in journals such as Comparative Politics, Global Asia, Government \& Opposition and International Interactions. Her book Gender, Informal Institutions and Political Recruitment: Explaining Male Dominance in Parliamentary Representation came out with Palgrave Macmillan in 2013.

Erik Melander (Sweden) is a Professor at the Department of Peace and Conflict Research and Director of the Uppsala Conflict Data Program, at Uppsala University, Sweden. He is the Deputy Program Leader of the East Asian Peace Program. His research interests concern gender, masculinities, conflict, and peace. His articles have been published in journals such as Conflict Management and Peace Science, European Journal of International Relations, Global Asia, International Interactions, International Studies Quarterly, Journal of Cold War Studies, Journal of Conflict resolution, Journal of Gender Studies, and Journal of Peace Research.

Funding information: This work was supported by Riksbankens Jubileumsfond under Grant M10-0100:1 “The East Asian Peace Since 1979: How Deep? How Can It Be explained?”.

Acknowledgements: The authors thank Kristine Eck, Håvard Hegre, Joakim Kreutz, David Laitin, Yongwook Ryu, Susanne Schaftenaar, Isak Svensson, Thommy Svensson and, last but not least, Stein Tønnesson for helpful comments and suggestions. The authors are equal contributors to this article; names are listed in alphabetical order. 
East Asia has undergone a remarkable shift from being the most war-torn region in the world to one of the most peaceful (Tønnesson 2009, Kivimäki 2010, Svensson 2011). At the same time, there is great concern that what is sometimes labelled as the 'East Asian Peace' (Tønnesson 2009, Kivimäki 2010, Svensson 2011) is shallow, and may not hold. Sabrerattling and high-pitched nationalist rhetoric in connection with several maritime disputes are seen as particularly worrying (Tønnesson, Melander et al. 2013). In 2011, the Secretary of State of the United States of America, Hillary Clinton, announced a pivot to the Pacific region, meaning increased US interest and engagement (Clinton 2011). The countries around the Pacific, including East Asia as well as the pivoting USA, make up a dynamic region characterized by contrasting trends of peace and economic development on the one hand, and nationalism, intolerance and military build-up on the other.

In research that seeks to explain attitudes that are favorable for peace, gender typically attracts considerable attention. For decades, scholars have reported that women tend to be more peaceful and less militaristic than men, something which is referred to as the 'gender gap' (Smith 1984, De Boer 1985, Shapiro and Mahajan 1986, Fite, Genest et al. 1990, Wilcox, Hewitt et al. 1996, Eichenberg 2003). However, studies have also existed for decades claiming that the gender gap is weakened or disappears when feminist attitudes are taken into account (Conover 1988, Cook and Wilcox 1991, Tessler and Warriner 1997, Tessler, Nachtwey et al. 1999, Brooks and Valentino 2011). In other words, feminism rather than biological sex may be what influences foreign policy public opinion. Yet the possibility that feminist attitudes matter more than gender has remained overlooked and under-researched in research in the field (Boussios and Cole 2012, Torabian and Abalakina 2012, Williams and Slusser 2014, Eichenberg and Stoll 2015). The focus on the gender gap as a difference between men and women is problematic, since it downplays the evident possibility that there 
are peaceful men too, and that these men may be both numerous and influential, particularly in societies that are generally more gender equal.

This article reexamines attitudes of individuals in relation to tolerance and pits the gender gap against the largely forgotten feminist gap (Conover 1988). We argue that the individual-level relationship between gender equality attitudes on the one hand, and tolerance and benevolence on the other, is under-researched, but also that key contributions about the potential effects of feminism have been mostly ignored in research on the gender gap in public opinion. We return to the notion that there may be a causal relationship between gender equality attitudes on the one hand, and peaceful attitudes on the other, and that this feminist gap also exists among men, as some previous studies indicated. Research on foreign policy attitudes has demonstrated that the relationship is complex, and that gender and feminist consciousness apply differently depending on whether the foreign policy questions addressed are hypothetical and about the use of violence in general, or on whether they are referring to a concrete situation (Conover and Sapiro 1993). In a series of novel empirical tests, we move from foreign policy attitudes and expand the analysis to more basic and general attitudes toward other nations and other religious groups. We demonstrate that the attitudes to gender equality, not gender itself, explain the attitudes towards "others". Using individual-level survey data from five countries around the Pacific: China, Indonesia, Japan, South Korea, and the United States of America, we show that both men and women who reject gender equality are much more hostile both to other nations and to minorities in their own country. We discuss the implications this has for policy as well as for future research. We suggest that it is time to move beyond the gender gap with its focus on the difference between men and women and the accompanying idea that there is something special about the attitudes of women, feminist women in particular. A more relevant task is to explain how both men and women may become more peaceful, and in this connection we cannot afford to overlook the role 
played by changing conceptions of manly honor and warrior cultures, i.e. militarized masculinity. In so doing, we want to bring the feminist gap back in.

\section{Gendering Hostile Attitudes}

There is a rich literature that seeks gendered patterns in public opinion on foreign policy issues. This literature commonly focuses on the so-called gender gap, i.e., the measured difference between the attitudes of women and men on a range of issues, including military spending and aggressive foreign policy. The term 'gender gap' refers to a variety of phenomena where there are discernible differences between men and women in political behavior or attitudes, such as the narrowing gender gaps in levels of mass participation, or the different electoral and partisan choices of men and women. There is also a well-documented gender gap in public opinion. Although there are discernible differences in the attitudes of men and women with regard to types of policy preferences - such as the fact that women are generally more positive towards increasing social welfare than men are - the most persistent and sizable differences have been declared to be the differences in attitudes towards the use of force (Shapiro and Mahajan 1986, Conover 1988). Women are less likely to advocate or support violent solutions than men are (Smith 1984, Page and Shapiro 1992, Peterson 1992, Tickner 1992, Wilcox, Hewitt et al. 1996).

In an American context, women and men differ in their use of violence as well as in their attitudes to violence. This is consistent for a variety of forms of violence: interpersonal, law enforcement and foreign policy (Smith 1984). When it comes to issues of foreign policy, women consistently appear less militaristic than men, in that they are less supportive of U.S. involvement in wars and of increasing defense spending (Conover and Sapiro 1993). The gender gap seems to widen when foreign policy issues are salient in society (Togeby 1994, 
Tessler, Nachtwey et al. 1999) and the differences are also more pronounced when it comes to foreign policy instruments rather than foreign policy goals. In other words, women and men agree on desirable outcomes, but in general have different views on how to get there (Fite, Genest et al. 1990, Regan and Paskeviciute 2003).

Much of the existing research emanates from research on policy attitudes in the United States. In studies of other countries, the results are not as clear. In a cross-national analysis of the gender gap in attitudes toward the Gulf War, gender differences are reported as modest, but with women being slightly less supportive of military action than men in almost all the cities studied (Wilcox, Hewitt et al. 1996). A study of Denmark showed that foreign policy attitudes did differ between men and women, but attributed these differences to the increased leftist mobilization of women (Togeby 1994). Studies of Middle Eastern countries suggest that the women and peace hypothesis, that has found support in the U.S. context and to some extent in Western Europe, does not hold for the Middle East. In the Middle East, women are not more pacific than men in their attitudes towards conflict, rather, attitudes to gender equality more generally have greater explanatory power over attitudes to whether the Arab-Israeli conflict should be resolved peacefully or with military force (Tessler and Warriner 1997, Tessler, Nachtwey et al. 1999). It is unclear if the mixed results are primarily due to different definitions of foreign policy attitudes, or to the fact that the surveys have been carried out in different contexts.

Moreover, the gender gap, where it exists, can be interpreted in several ways. The different views of women can be attributed to inherent characteristics of their sex, to their experiences of nurturing and motherhood, or to socialization and constructed gender roles. Research focusing on the latter vein claims that the difference between men and women is greatest in the case of topics that are strongly linked to issues that closely deal with differences in socialization: gun ownership, boxing, hunting and gun control (Smith 1984). The fact that 
women are more likely to feel sympathy for the disadvantaged in society than men may be attributed to women being part of a group that has traditionally been disadvantaged in society (Conover 1988). Gender gaps became more evident in the U.S. with the rise of the women's movement in the 1970s (Conover 1988). They also seem to be largest in countries with nationally organized feminist movements. It has been argued that such movements lead women to reflect on the links between their private experiences and public policies (Shapiro and Mahajan 1986, Togeby 1994, Wilcox, Hewitt et al. 1996). It is thus not surprising that we find a majority of women among those who take a political stand for equality between the sexes, who are in favor of gender equality and who call themselves feminists. In a study by Conover and Sapiro, there is some support for the gender gap and some support for a feminist gap, depending on the issue addressed (Conover and Sapiro 1993). Following this line of research, the feminist attitudes that we find among many women need are potential drivers of the relationship. At the very least, these findings propose that studies should consider a feminist gap, as well as a gender gap. In line with this proposal, our first hypothesis reflects our expectation that individuals who are more positive towards gender equality and feminism will also exhibit less hostility to out-groups.

\section{H1: Individuals who are more positive towards gender equality are less hostile to other} nations and religious minorities.

Although the gender gap, where identified, can be interpreted in different ways, most studies to date focus on the divergent views of women as compared to men. The implication of this is that much scholarly attention, as well as advocacy work, has been directed towards understanding the supposedly dovish role of women, and how they can be empowered in different contexts and thereby benefit peace (Anderlini 2000, Dornig and Goede 2010, Bjarnegård and Melander 2013). 
If we depart from a primarily constructivist view of gender, however, gender roles and attitudes about the suitable roles of women and men in society can and do change. Roles and expected behavior of men and women vary greatly across time and space. For instance, men can hold feminist views, while women can be non-feminists. Although we expect to find more women than men holding feminist views, our first hypothesis also encompasses the expectation that it is really the feminist orientation, and not the gender of the individual, that matters for hostility to other nations and religious minorities. We will elaborate a little more on this notion of a feminist gap. Even in studies such as the one conducted by Tessler and Warriner in the Middle East, where gender does not have any explanatory power over public opinion regarding foreign policy, attitudes to gender equality seem to matter (Tessler and Warriner 1997). Cook and Wilcox also argue in terms of a feminist gap; that it is the commitment of feminists to values of freedom, equality, and self-government that drives the results, rather than their gender (Cook and Wilcox 1991).

Needless to say, men, as well as women, can value freedom and equality and embrace tolerance and respect for the rights of the individual. We argue that it is likely that such values, emanating from close relationships formed early on in life, will translate into tolerance for other groups as well. Melander (2005), drawing on Tickner (2001) and Goldstein (2001), argues that "in societies characterized by more equal gender roles, the norms of respect and inviolability that characterize an individual's closest relations are also expected to carry over to more distant relations, thereby strengthening societal norms that reject abuse and violence" (see also Gleditsch, Wucherpfennig et al. 2011). In other words, in terms of causal direction, we find it plausible that norms and attitudes associated with the early and close familial relationships that an individual experiences affect the norms and attitudes associated with more abstract and distant societal relationships, such as religious minorities or other nationalities. 
From what we know about gender bias in research, it is not surprising that the focus has been on the divergent attitudes of women vis-à-vis the attitudes of men. Although most research in gender studies would agree that men are gendered beings to the same extent that women are, gender is still often used as a synonym for 'women'. Men often serve implicitly as the norm, while the focus of gendered scrutiny is on female-exceptional characteristics (Bjarnegård 2013).

"The categories of men and masculinity are frequently central to analyses, yet they remain taken for granted, hidden and unexamined. Men are both talked about and ignored, rendered simultaneously explicit and implicit. They are frequently at the center of discourse but they are rarely the focus of interrogation" (Collinson and Hearn 2001).

In this article, the attitudes of men will not be a backdrop against which we compare the divergent and presumably more dovish attitudes of women. Instead, we will explicitly scrutinize and assess the attitudes of men, too, assuming that the male gender is also subject to social construction, and changing across time and space. The expectations that families, schools, and societies have of boys will influence their outlook on the world around them. It will also matter for the way in which they regard other people, both people in their close vicinity and a general tolerance towards people they have never met. The attitudes that men have about other nationalities and minorities are, arguably, particularly important, considering the fact that men yield so much power over issues of war and peace in all contemporary societies. Identifying a mechanism that can explain under what circumstances the public opinion of men is more peaceful is arguably as important as yet again demonstrating the difference of women. Although one can certainly expect more women than men to be positive towards gender equality, both men and women who favor gender equality should be less 
hostile to other nations and minorities. That is to say, we do not think that the relationships specified in the hypothesis above are driven solely by the difference of feminist women. Instead, we expect that the relationship between a favorable attitude to gender equality and less hostility should hold also in analyses among men separately. This is our second hypothesis.

H2: The relationship between positive attitudes to gender equality and benign attitudes to other nations and religious minorities holds among men.

\section{Data}

We will use data from the Pew Global Attitudes Project (PGAP), a series of worldwide public opinion surveys which began in 2001. Since these data were not collected for the purposes of this study, we have selected those variables and countries we could find with the closest fit, and this selection was guided by the three main criteria. First, because research on the gender gap is biased towards the United States, we wanted to move beyond this empirical focus, while also maintaining comparability to earlier studies. Focusing on the Pacific region enables us to include the United States in the analysis, while adding several other countries as well. Second, we needed data on one or more dependent variables reflecting hostility to out-groups. In this connection, we reasoned that the meaning of survey questions about, for example, the perceived hostility or benevolence of the rising great power China, will differ dramatically in the regional context, so that people are likely to consider at least partially different aspects of China's rise depending on proximity. To increase the comparability and hence the validity of such attitudinal measures, we decided to focus on one geographical region. We wanted a geographical region which had at the same time sufficient commonality in this sense, and considerable variation in our phenomena of interest, i.e., approval of gender equality and 
hostility. The region around the Pacific fits our purposes well. By studying respondents from important countries in the region, we can investigate the individual-level determinants of hostile attitudes in a context which is sufficiently similar for the meaning of hostility to neighboring nations and minorities to be reasonably comparable. In other words, we believe that whether China is viewed as an enemy or as a partner has a relatively similar meaning in Japan and the United States, but probably entails very different connotations in, e.g., Botswana or Germany. Importantly, the Pacific region also has considerable variation in key variables, including conflict and gender equality. Third, we needed to include surveys with data on one or more indicators of approval of gender equality with general validity, as well as a set of reasonable control variables.

On the basis of these criteria, we chose to analyze a subset of five countries of the PGAP Spring 2010 survey dataset, with the responses from 6,670 individuals surveyed in China $(n=3262)$, Indonesia $(n=1000)$, Japan $(n=700)$, South Korea $(n=706)$, and the United States of America $(n=1002)$. All the surveys were based on national samples except in China, where the sample was disproportionally urban (the sample for China is $67 \%$ urban, whereas the population of China is $43 \%$ urban), and in Indonesia, where Papua and remote areas were excluded (the sample is representative of roughly $88 \%$ of the population). For more details on the survey, see The Pew Research Center (2010).

The research on the gender gap in foreign policy issues, and other issues of relevance for peace in general, has investigated a broad range of attitudes, and the variation in the exact questions is too great to review here. For example, some studies have included questions about how worried the respondent is over nuclear war and conventional war (Conover 1988, Cook and Wilcox 1991); several studies asks about attitudes to defense spending (Conover 1988, Cook and Wilcox 1991, Togeby 1994), or to the peace movement (Togeby 1994). Yet other studies in this genre ask more specific questions adapted to a certain situation, such as 
one's attitude to détente with the Soviet Union (Cook and Wilcox 1991), or views on alternative ways of dealing with the Arab-Israeli conflict (Tessler and Warriner 1997). In this study we analyze questions that are at the same time fundamental for foreign policy and peace, and adapted to comparative research in the Pacific regional context.

We chose to construct four alternative dependent variables. Whether people in the region view other countries as enemies or partners is at the same time a key foreign policy attitude, and arguably of importance for the prospects for peace. In particular, given the fast rise of China, how people in the region view China should be a central concern and a question with high validity in the sense that respondents will be able to relate to it and understand it (see e.g. Chan 2008). The first dependent variable, then, is based on a question asked in all countries except China: "Overall, do you think of China as more of a partner of (survey country), more of an enemy of (survey country), or neither?" Our first dependent variable chinaenemy takes the value 1 if the response is "More of an enemy", and 0 otherwise (if the respondent refused to answer, this variable is coded as missing).

It is evident that we cannot ask the question about how China is viewed in China itself. We therefore had to opt for separate analyses of respondents in China, with two different - but comparable - dependent variables. The rise of China is typically discussed in relation to the growing rivalry with presently strongest power in the Pacific region and globally, the United States of America. The prospect of violent conflict between China and the U.S. is a fundamental concern not only for the region, but for the world as a whole. The second dependent variable therefore asks respondents in China how they view the relationship between China and the U.S.: "Overall, how would you describe the relationship between China and the U.S.? Is it one of cooperation, one of hostility, or neither?" The variable chineseUShostile is coded 1 if the response is "One of hostility", and 0 otherwise (if the respondent refused to answer, this variable is coded as missing). 
While the looming power-transition in the relationship between China and the U.S. is of importance because of the not insignificant risk of world war, it is interesting to ask also how people in China view another, less formidable rival, namely India. China and India have fought over periods, and the degree to which people in China view India as an enemy arguably reflects attitudes of importance for both foreign policy and peace in the region. The third dependent variable, then, is also based on a question tapping attitudes in China: "Overall, how would you describe the relationship between China and India? Is it one of cooperation, one of hostility, or neither?" The variable chineseIndiahostile is coded 1 if the response is "One of hostility", and 0 otherwise (if the respondent refused to answer this variable is coded as missing).

In order to broaden the focus of our study we next turn to attitudes reflecting religious intolerance. In parts of the Pacific region conflict with religious elements has claimed many lives (in particular in Indonesia and the Philippines). Religious intolerance has the potential to color relations between countries in which different religions predominate. For these reasons religious intolerance is important both for domestic peace and foreign policy in the region. The fourth dependent variable therefore reflects unfavorable attitudes toward Jews, Christians, or Muslims, and is based on three questions: "Please tell me if you have a very favorable, somewhat favorable, somewhat unfavorable or very unfavorable opinion of Jews/Christians/Muslims?” A somewhat unfavorable attitude is coded 1, and a very unfavorable opinion is coded 2, and the highest value for any of the three religious groups is used for the variable intoleranceJewsChristiansMuslims (if the respondent refused to answer any of the three questions, this variable is coded as missing). The answers "very favorable" and "somewhat favorable" are coded as 0 . When analyzing this dependent variable, we do not include responses from China. The reason is that the question for a key control variable is not 
asked in China, namely "How important is religion in your life - very important, somewhat important, not too important, or not at all important?"

In sum, we have two alternative dependent variables reflecting attitudes in Japan, Indonesia, South Korea, and the United States on the perceived enmity of China, and on unfavorable opinions of Jews, Christians, and Muslims, respectively. We have to resort to two alternative dependent variables in order to be able to include China, which is something we perceive is crucial. The two alternative variables reflecting attitudes in China concern the enmity of the United States of America, and of India, respectively.

We use two alternative independent variables that are our main explanatory variables of interest. The first independent variable is based on the question: "Do you think women should have equal rights with men, or shouldn't they?" The variable womenequal takes the value 1 if the answer is "Should", and 0 otherwise (if the respondent refused to answer, this variable is coded as missing).

The second independent variable is based on the question: "What kind of marriage do you think is the more satisfying way of life, number 1 or number 2 ?" The respondent is shown a card and gets to choose between alternative 1, which reads "One where the husband provides for the family and the wife takes care of the house and children"; and alternative 2, which reads "One where the husband and wife both have jobs and both take care of the house and children". The variable equalmarriage takes the value 1 if the second alternative is chosen, and 0 otherwise (if the respondent refused to answer, this variable is coded as missing). The questions for both womenequal and equalmarriage were asked in all countries included in this study.

We also include a set of control variables. A first control variable has already been mentioned above, namely importancereligion. This variable is based on the following question: "How 
important is religion in your life - very important, somewhat important, not too important, or not at all important?" Our variable takes the value 3 if the answer is "very important", 2 if the answer is "somewhat important", 1 for "not too important", and 0 for "not at all important" ("Don't know" and refused to answer are coded as missing). People for whom religion is very important in life tend also to be less approving of gender equality and more unfavorably inclined towards one or more of the groups Jews, Christians, or Muslims. Hence, we need to control for religiosity, so as not to conflate any benign effects we may find of approval of gender equality and effects of a more secular outlook on life.

Our second control, sexfemale, is the sex of the respondent, with women coded 1 and men 0. As noted above, women have been found to be somewhat more approving of gender equality and less hardline on foreign policy and militarism - this is the so-called gender gap. Our theoretical argument implies that approval of gender equality should be related to less hostility to out-groups regardless of biological sex, and hence it becomes imperative to include respondent sex as a control.

The third control variable is intended to tap into two factors that we believe may be important both for attitudes to gender equality and chauvinism and intolerance. We control for education using an indicator in three steps, and the rationale for including this control is that people with higher education tend to be more favorable towards gender equality and less hostile towards out-groups.

Relatedly, the control internet is based on the question "Do you use the Internet, at least occasionally?", and is coded 1 for "Yes", and 0 otherwise. We believe that this variable can proxy for the extent to which an individual is informed about and follows current events. Internet is one of the main sources of news and debates these days, and being better informed about current affairs can be expected to be associated with internationalism. This variable is also an indicator of economic status, since the poorest people may not have access to the 
Internet. Interest in and knowledge about current events can be expected to be related to both gender equality and chauvinism/intolerance, and the same goes for economic affluence, and hence, we include internet as a control.

Our primary control for economic status is income, which reflects the respondent's income, standardized by country.

Our sixth control variable reflects satisfaction with the current developments in one's country, and is based on the question: "Overall, are you satisfied or dissatisfied with the way things are going in your country today? ". Our variable satisfiedcountry takes the value 1 if the response is "Satisfied", and 0 otherwise. We expect that people who are more dissatisfied are also more likely to seek comfort in traditional gender values and nationalism, and hence we include this control.

The seventh control, owncellphone, reflects whether the respondent owns a cell phone or not, and we view this variable as primarily picking up economic affluence, since the poorest people in the region are the least likely to own a cellphone.

The eighth control is intended to capture the respondent's ideological outlook with regard to market economy. It is based on the following question: "Please tell me whether you completely agree, mostly agree, mostly disagree or completely disagree with the following statements. Most people are better off in a market economy, even though some people are rich and some are poor." We assign the following values to our control variable marketeconomybetter: "Completely agree" $=3$; "Mostly agree" $=2$; "Mostly disagree"=1; "Completely disagree" $=0$. Previous research has shown that people who are committed to socialist ideology, and hence tend to disapprove of market economy, are somewhat more committed to gender equality. The thesis on the liberal peace holds that the values of trade are likely to go hand in hand with a benevolent attitude to other nations. Since one's attitude to 
market economy could be expected to be associated both with our dependent and independent variables, we include this control.

Finally, we are aware that the countries included in the study are diverse with regard to issues like the level of democracy and economic development. We expect the relationship between attitudes to gender equality and hostility to hold in different types of contexts, but we also include country dummies as controls for unique conditions in the included countries, which are not accounted for by our other variables. ${ }^{1}$

Three of our dependent variables are binary (chinaenemy, chineseUShostile, chineseIndiahostile), and the fourth dependent variable (intoleranceJewsChristiansMuslims) is an ordinal scale ranging from 0 to 2 . We will use logistic regression when analyzing the first three dependent variables, and ordinal logistic regression for the fourth dependent variable.

For two of our dependent variables - chinaenemy and intolerance - our tests will pool respondents from four countries, namely Indonesia, Japan, South Korea, and the USA. We present models with country-fixed effects to control for unique conditions, which are not captured by our other independent variables. However, in robustness tests shown in the appendix, we treat these tests as multilevel models, and allow random effects so that both the intercept and the slope of the gender equality variable may vary by country.

\footnotetext{
${ }^{1}$ We have run all models with the control variable 'age of the respondent' and it does not change the results.
} 


\section{Results}

First we will test H1: Individuals who are more positive towards gender equality are less hostile to other nations and religious minorities. Tables 1 and 2 present our test of H1. In Models 1 and 2 the dependent variable is chinaenemy, and the respondents are from Japan, Indonesia, South Korea, and the United States, with United States being the excluded reference category. In Models 3 and 4 the dependent variable is chineseUShostile, and all the respondents are from China. In Models 5 and 6 the dependent variable is chineseIndiahostile, and the respondents are again from China. Models 1-6 use logistic regression.

\section{[TABLE 1 ABOUT HERE]}

Table 2 presents the ordinal logistic regressions in Models 7 and 8, and the dependent variable is intoleranceJewsChristiansMuslims.

\section{[TABLE 2 ABOUT HERE]}

If we look at all eight models $1-8$, it is striking that our two indicators of approval of gender equality have negative signs and are statistically significant in all models except Model 6. In other words, favoring gender equality in terms of equal rights and equality in marriage is significantly associated with less hostile views of other nations and minority groups. This represents strong support for H1. Individuals who are more approving of gender equality are clearly less likely to espouse hostile views, and this holds when taking into account respondent sex as well as a number of other control variables. The coefficient for sexfemale has a negative sign, but is only significant in three models $(3,7,8)$ out of eight. Clearly, biological sex is much less important than attitudes to gender equality for explaining hostility, just as we expected. The effects of womenequal and equalmarriage uncovered in Models 1-8 deserve further explication. The magnitude of effects is not immediately evident from the coefficients in logistic regression. Using the software Clarify, we calculated the predicted 
probabilities of holding the attitudes reflected in the dependent variables associated with different attitudes to gender equality (King, Tomz et al. 2000, Tomz, Wittenberg et al. 2003). Table 3 presents the predictions obtained corresponding to Models 1-8, respectively.

\section{[TABLE 3 ABOUT HERE]}

For example, Model 1 shows that the predicted probability that someone who thinks that women should not have equal rights will consider China to be more of an enemy is $21 \%$, whereas the corresponding probability that someone who approves of equal rights will consider China to be more of an enemy is only $15 \%$. In other words, the risk of being hostile to China is $29 \%$ lower among people who think that women should have equal rights (the difference in six percentage points corresponds to a reduction of risk of $29 \%$ since $.15 / .21=0.71)$. All effects illustrated are statistically significant, except the effect in Model 6, which therefore is in parentheses. By social science standards, the effects of attitudes to gender equality shown in Table 3 are strong. Indeed, the effects are strong enough to be of substantial importance. For example, assuming that our models are correct, if people in China who do not approve of gender equality were to change their attitudes and support gender equality instead, the amount of hostility among the population of China toward the United States and India would be more than halved (Models 3 and 5).

With regard to the control variables in Models 1-8, the results are mostly inconsistent, with the notable exception that those who are more satisfied with their country are less hostile and intolerant. Indonesians are the least hostile to China (Models 1-2), and Americans are the least intolerant of religious minorities (Models 7-8).

In the above, we have presented evidence that individuals' approval of gender equality is strongly associated with less hostility to other nations and minorities, and that this relationship holds when taking biological sex into account. Indeed, attitudes to gender equality turned out 
to be much more important than respondent sex. Now we proceed to test our second hypothesis (H2): The relationship between positive attitudes to gender equality and benign attitudes to other nations and religious minorities holds among men. By including the control sexfemale in Models 1-8, we have already established that the benign effect of approval of gender equality holds when the possible effect of respondent sex is also taken into account. Nevertheless, the fact that it is likely that women are more positive to gender equality than men underlines that separate tests for men and women might be called for. Thus, we expect that when we conduct analyses on men only, men who approve of gender equality will be less hostile to other nations and minorities than other men.

Table 4 is identical to Table 1 except that Models 9-14 use only male respondents. Likewise, Table 5 is identical to Table 2 but with male respondents only.

\section{[TABLE 4 ABOUT HERE]}

\section{[TABLE 5 ABOUT HERE]}

The variables reflecting approval of gender equality have the predicted negative sign and are statistically significant in six (Models 9-13, and 15) out of the eight models with only male respondents. ${ }^{2}$ Hence, we find support also for $\mathrm{H} 2$. In other words, the association between approval of gender equality and less hostility, exists not only among women (who tend to be more supportive of gender equality), but also among men. The support for $\mathrm{H} 2$ underlines that approval of gender equality is much more important than biological sex for understanding the variation among individuals in hostility.

\footnotetext{
${ }^{2}$ When the same models were run with women only, they yielded similar results. The variables reflecting approval of gender equality had a negative sign in each of the models, and were statistically significant in seven out of eight models. See appendix.
} 
To summarize, we have found support for our two hypotheses. Favoring gender equality in terms of equal rights and equality in marriage is significantly associated with less hostile views of other nations and minority groups. Although different dependent variables are used for China, the results are pointing in the same direction. This association between approval of gender equality and less hostility is not only relevant among women and is not driven by the feminism of many women. Instead, it holds also for an analysis of men only. Men who are supportive of gender equality tend to also be more tolerant towards other nations and individuals of other religions. The strong focus on the attitudes of women in the discipline therefore seems somewhat unwarranted. The key to peaceful attitudes could just as well lie in the attitudes of men and to what extent they abandon a focus on honor and militarized masculinity in favor of more tolerant and less hostile attitudes.

\section{Robustness tests}

All the models mentioned in this section are presented in the online appendix. As noted above, the control variable age was added to Models 1-8, but it was never significant and hence we conclude that it does not belong in the model. As also reported above, Models 9-16 were repeated with only female respondents. We then repeated Models 1, 2, 7 and 8 as multilevel models allowing for random effects so that both the intercept and the slope for the gender equality variable varied by country. The coefficient for gender equality attitudes was significant in three out of these four models.

\section{Conclusion}

This study strengthens the individual-level notion that tolerant attitudes towards those close to us translate into tolerant attitudes also towards those who are perceived as being different 
from us. Although similar results were presented almost 20 years ago, these studies have left little imprint on the public opinion literature on the gender gap. In order for this literature not to stagnate around a continued focus on differences between men and women in a given society, this study points to a need to study the variation among men as well as differences between societies.

Hostile attitudes to other nations and to minorities seem to be fueled by negative attitudes to gender equality. Building on earlier research, we interpret our findings to mean that signals sent by people close to us about the different value of people of the other sex may also transfer into ideas about the different value of people from other nations or of other beliefs (c.f. the review of the literature on the origin of gender equal attitudes in Hudson and Boer 2012). The feminist argument that honor cultures which emphasize the value of militarized masculinity entail aspects of hostility to out-groups thus seems to hold true in the Pacific region and on the individual level, regardless of whether the out-group is of a different nationality or a different religion. This is a very different argument from the notion that women are inherently more peaceful than men. We are able to show that also men who reject gender equality are much more hostile to other nations and minorities than men with more gender-equal attitudes. Therefore, our cross-cultural findings from five countries that attitudes to gender equality are a strong determinant of hostility while biological sex is not, suggest that other studies of nationalism and intolerance would benefit from taking measures of gender inequality into account.

We thus see a need to focus on understanding where values and attitudes come from if we are to understand hostility. Our results strongly suggest that it is attitudes to gender equality, and not biological sex, which is the crucial factor behind the gender gap. Indeed, we show that this relationship between a favorable view of gender equality and less hostility holds both among men and women when analyzed separately. We are not the first to argue that the gender gap 
disappears when gender-equal attitudes are taken into account, but this article seeks to remind public opinion researchers about this finding, and demonstrates that it still holds, with new data and in a new empirical context. 


\section{References}

Anderlini, S. N. (2000). Women at the Peace Table. Making a Difference. New York, United Nations Development Fund for Women (UNIFEM).

Bjarnegård, E. (2013). Gender, Informal Institutions and Political Recruitment: Explaining Male Dominance in Parliamentary Representation. Houndmills, Basingstoke, Palgrave Macmillan.

Bjarnegård, E. and E. Melander (2013). "Revisiting Representation: Communism, Women in Politics, and the Decline of Armed Conflict in East Asia." International Interactions 39(4): 558-574.

Boussios, E. and S. Cole (2012). "An Analysis of Univer what Conditions Americans Support the Use of Military Force Abroad in Terrorist and Humanitarian Situations." Journal of Applied Security Research 7(4): 417-438.

Brooks, D. J. and B. Valentino (2011). "A War of One's Own: Understanding the Gender Gap in Support for War." Public Opinion Quarterly 75(2): 270-286.

Chan, S. (2008). China, the U.S., and the Power-Transition Theory: A Critique. London, Routledge.

Clinton, H. (2011). "America's Pacific century." Foreign Policy 189(1): 56-63.

Collinson, D. L. and J. Hearn (2001). Naming Men as Men: Implications for Work, Organization, and Management. The Sociology of Masculinity. F. Barrett and S. Whitehead. Cambridge, Polity Press.

Conover, P. J. (1988). "Feminists and the Gender Gap." Journal of Politics 50(4).

Conover, P. J. and V. Sapiro (1993). "Gender, Feminist Consciousness, and War." American Journal of Political Science 37(4): 1079-1099.

Cook, E. A. and C. Wilcox (1991). "Feminism and the Gender Gap - A Second Look." The Journal of Politics 53(4).

De Boer, C. (1985). "The Polls: The European peace movement and deployment of nuclear missiles." Public Opinion Quarterly 49(1): 119-132.

Dornig, S. and N. Goede (2010). Ten Years of Women, Peace and Security. INEF Policy Brief, Universität Duisburg Essen. 
Eichenberg, R. C. (2003). "Gender differences in public attitudes toward the use of force by the United States, 1990-2003." International Security 28(1): 110-141.

Eichenberg, R. C. and R. J. Stoll (2015). "The Acceptability of War and Support for Defense Spending, Evidence for Fourteen Democracies, 2004-2013." Journal of Conflict Resolution online first publication: $1-23$.

Fite, D., et al. (1990). "Gender Differences in Foreign Policy Attitudes: A Longitudinal Analysis." American Politics Research 18.

Gleditsch, K. S., et al. (2011). "Polygyny or Misogyny? Reexamining the "First Law of Intergroup Conflict"." The Journal of Politics 73(1): 265-270.

Goldstein, J. S. (2001). War and Gender: How Gender Shapes the War System and Vice Versa. Cambridge, Cambridge University Press.

Hudson, V. M. and A. M. d. Boer (2012). A feminist evolutionary analysis of the relationship between violence against and inequitable treatment of women, and conflict within and between human collectives, including nation-states. . The Oxford Handbook of Evolutionary Perspectives on Violence, Homicide, and War. T. K. Shackelford and V. A. WeekesShackelford. Oxford, Oxford University Press.

King, G., et al. (2000). "Making the Most of Statistical Analyses: Improving Interpretation and Presentation." American Journal of Political Science 44: 347-361.

Kivimäki, T. (2010). "East Asian relative peace - does it exist? What is it?" The Pacific Review 23(4): 503-526.

Melander, E. (2005). "Gender Equality and Intrastate Armed Conflict." International Studies Quarterly 49(4): 695-714.

Page, B. I. and R. Y. Shapiro (1992). The Rational Public: Fifty Years of Trends in Americans' Public Preferences. Chicago, IL, University of Chicago Press.

Peterson, S. (1992). Gendered States: Feminist Revisions of International Relations Theory. Boulder, CO, Lynne Rienner.

Regan, P. M. and A. Paskeviciute (2003). "Women's Access to Politics and Peaceful States." Journal of Peace Research 40(3): 287-302.

Shapiro, R. Y. and H. Mahajan (1986). "Gender Differences in Policy Preferences: A Summary of Trends From the 1960s to the 1980s." The Public Opinion Quarterly 50(1): 42 61 . 
Smith, T. W. (1984). "Gender and Attitudes Toward Violence." The Public Opinion Quarterly 48(1): 384-396.

Svensson, I. (2011). "East Asian Peacemaking: Exploring the patterns of conflict management and conflict settlement in East Asia." Asian Perspective 35(2): 163-185.

Tessler, M., et al. (1999). "Further Tests of the Women and Peace Hypothesis: Evidence from Cross-National Survey Research in the Middle East." International Studies Quarterly 43(3): 519-531.

Tessler, M. and I. Warriner (1997). "Gender, Feminism, and Attitudes Toward International Conflict." World Politics 49: 250-281.

Tickner, J. A. (1992). Gender in International Relations. New York, Colombia University Press.

Tickner, J. A. (2001). Gendering World Politics. New York, Colombia University Press.

Togeby, L. (1994). "The Gender Gap in Foreign Policy Attitudes." Journal of Peace Research 31(4): 375-392.

Tomz, M., et al. (2003). "CLARIFY: Software for interpreting and presenting statistical results. Version 2.1." Journal of Statistical Software 8(1).

Torabian, S. and M. Abalakina (2012). "Attitudes toward War in the United States and Iran." Iranian Studies 45(4): 463-478.

Tønnesson, S. (2009). "What is it that best explains the East Asian Peace since 1979? A Call for a Research Agenda." Asian Perspective 33(1): 111-136.

Tønnesson, S., et al. (2013). The fragile peace in East and South East Asia. SIPRI Yearbook 2013: Armaments, Disarmament and International Security. Oxford and New York, Oxford University Press.

Wilcox, C., et al. (1996). "The Gender Gap in Attitudes Toward the Gulf War: A CrossNational Perspective." Journal of Peace Research 33(1): 67-82.

Williams, D. M. and S. R. Slusser (2014). "Americans and Iraq, twelve years apart:

Comparing support for the \{US \} wars in Iraq." The Social Science Journal 51(2): 231-239. 
Table I. Explaining Hostility among Men and Women around the Pacific

MODEL 1 MODEL 2 MODEL 3 MODEL 4 MODEL 5 MODEL 6

\begin{tabular}{|c|c|c|c|c|c|c|}
\hline \multirow{2}{*}{$\begin{array}{r}\text { DEPENDENT VARIABLE: } \\
\text { COUNTRIES: } \\
\text { EQUAL RIGHTS FOR WOMEN }\end{array}$} & \multicolumn{2}{|c|}{$\begin{array}{l}\text { chinaenemy } \\
\text { ID, JP, KR, US }\end{array}$} & \multicolumn{2}{|c|}{$\begin{array}{c}\text { chineseUShostile } \\
\text { RC }\end{array}$} & \multicolumn{2}{|c|}{$\begin{array}{c}\text { chineselndiahostile } \\
\text { RC }\end{array}$} \\
\hline & -0.403 & & -1.020 & & -1.206 & \\
\hline & $(0.164)^{*}$ & & $(0.226)^{* *}$ & & $(0.219)^{* *}$ & \\
\hline \multirow[t]{2}{*}{ EQUAL MARRIAGE BETTER } & & -0.434 & & -0.574 & & -0.193 \\
\hline & & $(0.105)^{* *}$ & & $(0.137)^{* *}$ & & (0.147) \\
\hline \multirow[t]{2}{*}{ MARKET ECONOMY BETTER } & 0.034 & 0.008 & -0.239 & -0.269 & -0.156 & -0.200 \\
\hline & $(0.068)$ & $(0.068)$ & $(0.089)^{* *}$ & $(0.089)^{* *}$ & $(0.090)$ & $(0.090)^{*}$ \\
\hline \multirow[t]{2}{*}{ INTERNET USER } & 0.387 & 0.402 & -0.147 & -0.111 & 0.058 & 0.066 \\
\hline & $(0.150)^{* *}$ & $(0.151)^{* *}$ & $(0.146)$ & $(0.146)$ & $(0.144)$ & $(0.144)$ \\
\hline \multirow[t]{2}{*}{ EDUCATION } & -0.185 & -0.198 & 0.048 & 0.068 & -0.105 & -0.107 \\
\hline & $(0.094)^{*}$ & $(0.095)^{*}$ & $(0.095)$ & $(0.096)$ & $(0.095)$ & $(0.096)$ \\
\hline \multirow[t]{2}{*}{ FEMALE } & -0.138 & -0.144 & -0.255 & -0.220 & -0.233 & -0.229 \\
\hline & $(0.099)$ & $(0.100)$ & $(0.123)^{*}$ & $(0.123)$ & $(0.123)$ & $(0.123)$ \\
\hline \multirow[t]{2}{*}{ SATISFIED WITH COUNTRY } & -0.271 & -0.252 & -0.583 & -0.561 & -0.434 & -0.421 \\
\hline & $(0.113)^{*}$ & $(0.115)^{*}$ & $(0.150)^{* *}$ & $(0.152)^{* *}$ & $(0.155)^{* *}$ & $(0.157)^{* *}$ \\
\hline \multirow[t]{2}{*}{ INCOME } & 0.063 & 0.068 & -0.108 & -0.072 & -0.027 & -0.010 \\
\hline & $(0.053)$ & $(0.054)$ & $(0.064)$ & $(0.064)$ & $(0.067)$ & $(0.068)$ \\
\hline \multirow[t]{2}{*}{ CELLPHONE OWNER } & -0.253 & -0.178 & 0.062 & 0.025 & 0.513 & 0.494 \\
\hline & $(0.160)$ & $(0.162)$ & $(0.215)$ & $(0.216)$ & $(0.254)^{*}$ & $(0.253)$ \\
\hline \multirow[t]{2}{*}{ IMPORTANCE OF RELIGION } & -0.054 & -0.085 & & & & \\
\hline & $(0.054)$ & $(0.055)$ & & & & \\
\hline \multirow[t]{2}{*}{ INDONESIA } & -0.714 & -0.643 & & & & \\
\hline & $(0.201)^{* *}$ & $(0.195)^{* *}$ & & & & \\
\hline \multirow[t]{2}{*}{ JAPAN } & 0.068 & 0.030 & & & & \\
\hline & $(0.162)$ & $(0.165)$ & & & & \\
\hline \multirow[t]{2}{*}{ SOUTH KOREA } & 0.917 & 0.851 & & & & \\
\hline & $(0.138)^{* *}$ & $(0.140)^{* *}$ & & & & \\
\hline \multirow[t]{2}{*}{ CONSTANT } & -0.761 & -0.760 & -0.202 & -0.700 & -0.728 & -1.632 \\
\hline & $(0.324)^{*}$ & $(0.304)^{*}$ & $(0.356)$ & $(0.317)^{*}$ & (0.378) & $(0.349)^{* *}$ \\
\hline$N$ & 2,899 & 2,850 & 3,115 & 3,105 & 3,115 & 3,106 \\
\hline
\end{tabular}

$* \mathrm{p}<0.05 ; * * \mathrm{p}<0.01$

$\mathrm{ID}=$ Indonesia, $\mathrm{JP}=$ Japan, $\mathrm{KR}=$ Korea, US= the United States, $\mathrm{RC}=$ Republic of China 
Table II. Explaining Intolerance among Men and Women in Indonesia, Japan, South Korea and the USA

MODEL 7

MODEL 8

\begin{tabular}{|c|c|c|}
\hline $\begin{array}{r}\text { DEPENDENT VARIABLE: } \\
\text { COUNTRIES: }\end{array}$ & \multicolumn{2}{|c|}{$\begin{array}{c}\text { intoleranceJewsChristiansMuslims } \\
\text { ID, JP, KR, US }\end{array}$} \\
\hline \multirow[t]{2}{*}{ EQUAL RIGHTS FOR WOMEN } & -0.365 & \\
\hline & $(0.117)^{* *}$ & \\
\hline \multirow[t]{2}{*}{ EQUAL MARRIAGE BETTER } & & -0.207 \\
\hline & & $(0.093)^{*}$ \\
\hline \multirow[t]{2}{*}{ MARKET ECONOMY BETTER } & -0.090 & -0.091 \\
\hline & (0.059) & $(0.059)$ \\
\hline \multirow[t]{2}{*}{ INTERNET USER } & -0.204 & -0.190 \\
\hline & $(0.138)$ & $(0.139)$ \\
\hline \multirow[t]{2}{*}{ EDUCATION } & 0.015 & 0.018 \\
\hline & (0.091) & $(0.091)$ \\
\hline \multirow[t]{2}{*}{ FEMALE } & -0.237 & -0.249 \\
\hline & $(0.090)^{* *}$ & $(0.089)^{* *}$ \\
\hline \multirow[t]{2}{*}{ SATISFIED WITH COUNTRY } & -0.220 & -0.191 \\
\hline & $(0.097)^{*}$ & $(0.097)^{*}$ \\
\hline \multirow[t]{2}{*}{ INCOME } & -0.046 & -0.065 \\
\hline & $(0.050)$ & $(0.050)$ \\
\hline \multirow[t]{2}{*}{ CELLPHONE OWNER } & -0.074 & -0.040 \\
\hline & $(0.117)$ & $(0.117)$ \\
\hline \multirow[t]{2}{*}{ IMPORTANCE OF RELIGION } & -0.079 & -0.067 \\
\hline & $(0.061)$ & $(0.062)$ \\
\hline \multirow[t]{2}{*}{ INDONESIA } & 1.920 & 1.998 \\
\hline & $(0.185)^{* *}$ & $(0.182)^{* *}$ \\
\hline \multirow[t]{2}{*}{ JAPAN } & 0.850 & 0.899 \\
\hline & $(0.181)^{* *}$ & $(0.183)^{* *}$ \\
\hline \multirow[t]{2}{*}{ SOUTH KOREA } & 0.664 & 0.664 \\
\hline & $(0.174)^{* *}$ & $(0.175)^{* *}$ \\
\hline \multirow[t]{2}{*}{ CONSTANT } & 1.134 & 1.392 \\
\hline & $(0.307)^{* *}$ & $(0.299)^{* *}$ \\
\hline \multirow[t]{2}{*}{ CONSTANT } & 2.940 & 3.176 \\
\hline & $(0.313)^{* *}$ & $(0.306)^{* *}$ \\
\hline$N$ & 2,858 & 2,813 \\
\hline$* p<0.05 ; * * p<0.01$ & & \\
\hline
\end{tabular}


Table III. Predicted Effects of Attitudes to Gender Equality on Hostility

\begin{tabular}{|c|c|c|c|c|}
\hline & $\begin{array}{l}\text { China is } \\
\text { More of an } \\
\text { Enemy }\end{array}$ & $\begin{array}{l}\text { China-US } \\
\text { Relationship } \\
\text { is One of } \\
\text { Hostility }\end{array}$ & $\begin{array}{l}\text { China-India } \\
\text { Relationship is } \\
\text { One of Hostility }\end{array}$ & $\begin{array}{c}\text { Unfavorable } \\
\text { Opinion of Jews, } \\
\text { Christians, or } \\
\text { Muslims }\end{array}$ \\
\hline & Model 1 & Model 3 & Model 5 & Model 7 \\
\hline Countries: & $I D, J P, K R, U S$ & $\mathrm{RC}$ & $\mathrm{RC}$ & $I D, J P, K R, U S$ \\
\hline $\begin{array}{c}\text { Women should not have } \\
\text { equal rights }\end{array}$ & $21 \%$ & $23 \%$ & $25 \%$ & $2.2 \%$ \\
\hline \multirow[t]{2}{*}{$\begin{array}{l}\text { Women should have equal } \\
\text { rights }\end{array}$} & $15 \%$ & $10 \%$ & $9 \%$ & $1.5 \%$ \\
\hline & Model 2 & Model 4 & Model 6 & Model 8 \\
\hline Countries: & $I D, J P, K R, U S$ & $\mathrm{RC}$ & $\mathrm{RC}$ & $I D, J P, K R, U S$ \\
\hline $\begin{array}{l}\text { A marriage where the } \\
\text { husband provides for the } \\
\text { family and the wife takes } \\
\text { care of the house and } \\
\text { children is more satisfying }\end{array}$ & $20 \%$ & $15 \%$ & $(11 \%)$ & $1.9 \%$ \\
\hline $\begin{array}{l}\text { A marriage where the } \\
\text { husband and the wife both } \\
\text { have jobs and both take care } \\
\text { of the house is more } \\
\text { satisfying }\end{array}$ & $14 \%$ & $9 \%$ & (9\%) & $1.6 \%$ \\
\hline
\end{tabular}

$\mathrm{ID}=$ Indonesia, $\mathrm{JP}=\mathrm{Japan}, \mathrm{KR}=$ Korea, $\mathrm{US}=$ the United States, $\mathrm{RC}=\mathrm{Republic}$ of China 
Table V. Explaining Intolerance among Men in Indonesia, Japan, South Korea, and the USA

\begin{tabular}{|c|c|c|}
\hline & MODEL 15 & MODEL 16 \\
\hline $\begin{array}{r}\text { DEPENDENT VARIABLE: } \\
\text { COUNTRIES: }\end{array}$ & \multicolumn{2}{|c|}{$\begin{array}{c}\text { intoleranceJewsChristiansMuslims } \\
\text { ID, JP, KR, US }\end{array}$} \\
\hline \multirow[t]{2}{*}{ EQUAL RIGHTS FOR WOMEN } & -0.343 & \\
\hline & $(0.160)^{*}$ & \\
\hline \multirow[t]{2}{*}{ EQUAL MARRIAGE BETTER } & & -0.188 \\
\hline & & $(0.127)$ \\
\hline \multirow[t]{2}{*}{ MARKET ECONOMY BETTER } & 0.008 & 0.037 \\
\hline & $(0.080)$ & $(0.081)$ \\
\hline \multirow[t]{2}{*}{ INTERNET USER } & -0.288 & -0.265 \\
\hline & $(0.185)$ & $(0.186)$ \\
\hline \multirow[t]{2}{*}{ EDUCATION } & 0.049 & 0.048 \\
\hline & $(0.124)$ & $(0.124)$ \\
\hline \multirow[t]{2}{*}{ SATISFIED WITH COUNTRY } & -0.218 & -0.178 \\
\hline & $(0.135)$ & $(0.135)$ \\
\hline \multirow[t]{2}{*}{ INCOME } & 0.023 & 0.001 \\
\hline & $(0.067)$ & $(0.068)$ \\
\hline \multirow[t]{2}{*}{ CELLPHONE OWNER } & -0.076 & -0.049 \\
\hline & $(0.168)$ & $(0.168)$ \\
\hline \multirow[t]{2}{*}{ IMPORTANCE OF RELIGION } & -0.076 & -0.078 \\
\hline & $(0.082)$ & $(0.084)$ \\
\hline \multirow[t]{2}{*}{ INDONESIA } & 1.701 & 1.829 \\
\hline & $(0.254)^{* *}$ & $(0.246)^{* *}$ \\
\hline \multirow[t]{2}{*}{ JAPAN } & 0.809 & 0.815 \\
\hline & $(0.238)^{* *}$ & $(0.242)^{* *}$ \\
\hline \multirow[t]{2}{*}{ SOUTH KOREA } & 0.656 & 0.632 \\
\hline & $(0.230)^{* *}$ & $(0.233)^{* *}$ \\
\hline \multirow[t]{2}{*}{ CONSTANT } & 1.208 & 1.495 \\
\hline & $(0.404)^{* *}$ & $(0.390)^{* *}$ \\
\hline \multirow[t]{2}{*}{ CONSTANT } & 3.033 & 3.291 \\
\hline & $(0.413)^{* *}$ & $(0.400)^{* *}$ \\
\hline$N$ & 1,386 & 1,361 \\
\hline$* p<0.05 ; * * p<0.01$ & & \\
\hline
\end{tabular}


Appendix Table I. Adding Age to Models 1-6

\begin{tabular}{|c|c|c|c|c|c|c|}
\hline & $\begin{array}{l}\text { MODEL } \\
\text { A1 }\end{array}$ & $\begin{array}{l}\text { MODEL } \\
\text { A2 }\end{array}$ & $\begin{array}{l}\text { MODEL } \\
\text { A3 }\end{array}$ & $\begin{array}{l}\text { MODEL } \\
\text { A4 }\end{array}$ & $\begin{array}{l}\text { MODEL } \\
\text { A5 }\end{array}$ & $\begin{array}{l}\text { MODEL } \\
\text { A6 }\end{array}$ \\
\hline $\begin{array}{l}\text { Dependent Variable: } \\
\text { Countries: }\end{array}$ & \multicolumn{2}{|c|}{$\begin{array}{l}\text { chinaenemy } \\
\text { ID, JP, KR, US }\end{array}$} & \multicolumn{2}{|c|}{$\begin{array}{c}\text { chineseUShostile } \\
\text { RC }\end{array}$} & \multicolumn{2}{|c|}{$\begin{array}{c}\text { chineselndiahostile } \\
\text { RC }\end{array}$} \\
\hline \multirow[t]{2}{*}{$\begin{array}{l}\text { Equal Rights for } \\
\text { Women }\end{array}$} & -0.388 & & -1.022 & & -1.207 & \\
\hline & $(0.165)^{*}$ & & $(0.227)^{* *}$ & & $(0.219)^{* *}$ & \\
\hline \multirow[t]{2}{*}{ Equal Marriage Better } & & -0.443 & & -0.576 & & -0.192 \\
\hline & & $(0.105)^{* *}$ & & $(0.137)^{* *}$ & & $(0.147)$ \\
\hline \multirow{2}{*}{$\begin{array}{l}\text { Market Economy } \\
\text { Better }\end{array}$} & 0.051 & 0.024 & -0.238 & -0.269 & -0.157 & -0.201 \\
\hline & $(0.068)$ & (0.069) & $(0.089)^{* *}$ & $(0.089)^{* *}$ & $(0.090)$ & $(0.090)^{*}$ \\
\hline \multirow[t]{2}{*}{ Internet User } & 0.294 & 0.300 & -0.045 & 0.005 & -0.036 & -0.033 \\
\hline & $(0.161)$ & $(0.162)$ & (0.159) & $(0.160)$ & $(0.157)$ & $(0.157)$ \\
\hline \multirow[t]{2}{*}{ Education } & -0.183 & -0.195 & 0.060 & 0.080 & -0.114 & -0.116 \\
\hline & $(0.095)$ & $(0.096)^{*}$ & $(0.096)$ & $(0.096)$ & $(0.095)$ & $(0.096)$ \\
\hline \multirow[t]{2}{*}{ Female } & -0.147 & -0.154 & -0.233 & -0.197 & -0.252 & -0.248 \\
\hline & (0.099) & $(0.100)$ & $(0.124)$ & $(0.124)$ & $(0.123)^{*}$ & $(0.124)^{*}$ \\
\hline \multirow{2}{*}{ Satisfied with Country } & -0.293 & -0.273 & -0.597 & -0.574 & -0.424 & -0.411 \\
\hline & $(0.114)^{*}$ & $(0.116)^{*}$ & $(0.151)^{* *}$ & $(0.152)^{* *}$ & $(0.155)^{* *}$ & $(0.157)^{* *}$ \\
\hline \multirow[t]{2}{*}{ Income } & 0.073 & 0.078 & -0.109 & -0.074 & -0.024 & -0.007 \\
\hline & $(0.054)$ & $(0.054)$ & $(0.063)$ & $(0.064)$ & $(0.068)$ & $(0.068)$ \\
\hline \multirow[t]{2}{*}{ Cellphone Owner } & -0.291 & -0.221 & 0.137 & 0.108 & 0.447 & 0.423 \\
\hline & $(0.162)$ & $(0.163)$ & $(0.220)$ & $(0.221)$ & $(0.258)$ & $(0.257)$ \\
\hline \multirow{2}{*}{$\begin{array}{l}\text { Importance of } \\
\text { Religion }\end{array}$} & -0.034 & -0.064 & & & & \\
\hline & $(0.055)$ & $(0.056)$ & & & & \\
\hline \multirow[t]{2}{*}{ Indonesia } & -0.876 & -0.826 & & & & \\
\hline & $(0.231)^{* *}$ & $(0.227)^{* *}$ & & & & \\
\hline \multirow[t]{2}{*}{ Japan } & 0.086 & 0.049 & & & & \\
\hline & $(0.164)$ & $(0.166)$ & & & & \\
\hline \multirow[t]{2}{*}{ South Korea } & 0.880 & 0.813 & & & & \\
\hline & $(0.140)^{* *}$ & $(0.142)^{* *}$ & & & & \\
\hline \multirow[t]{2}{*}{ Age } & -0.006 & -0.006 & 0.010 & 0.010 & -0.009 & -0.009 \\
\hline & $(0.004)$ & $(0.004)$ & $(0.006)$ & $(0.006)$ & $(0.006)$ & $(0.006)$ \\
\hline \multirow[t]{2}{*}{ Constant } & -0.447 & -0.401 & -0.709 & -1.259 & -0.277 & -1.161 \\
\hline & (0.399) & $(0.386)$ & $(0.467)$ & $(0.440)^{* *}$ & $(0.486)$ & $(0.465)^{*}$ \\
\hline $\mathbf{N}$ & 2,864 & 2,813 & 3,115 & 3,105 & 3,115 & 3,106 \\
\hline
\end{tabular}

${ }^{*} p<0.05 ;{ }^{* *} p<0.01$

$\mathrm{ID}=$ Indonesia, $\mathrm{JP}=\mathrm{Japan}, \mathrm{KR}=\mathrm{Korea}, \mathrm{US}=$ the United States, $\mathrm{RC}=$ Republic of China 
Appendix Table II. Adding Age to Models 7-8

MODEL A7 MODEL A8

\begin{tabular}{|c|c|c|}
\hline \multirow{2}{*}{$\begin{array}{r}\begin{array}{r}\text { Dependent Variable: } \\
\text { Countries: }\end{array} \\
\text { EQUAL RIGHTS FOR WOMEN }\end{array}$} & \multicolumn{2}{|c|}{$\begin{array}{c}\text { intolerance JewsChristiansMuslims } \\
\text { ID, JP, KR, US }\end{array}$} \\
\hline & -0.331 & \\
\hline & $(0.119)^{* *}$ & \\
\hline \multirow[t]{2}{*}{ EQUAL MARRIAGE BETTER } & & -0.205 \\
\hline & & $(0.093)^{*}$ \\
\hline \multirow[t]{2}{*}{ MARKET ECONOMY BETTER } & -0.086 & -0.092 \\
\hline & (0.059) & $(0.060)$ \\
\hline \multirow[t]{2}{*}{ INTERNET USER } & -0.203 & -0.180 \\
\hline & $(0.146)$ & $(0.147)$ \\
\hline \multirow[t]{2}{*}{ EDUCATION } & 0.0216 & -0.025 \\
\hline & $(0.092)$ & $(0.092)$ \\
\hline \multirow[t]{2}{*}{ FEMALE } & & -0.252 \\
\hline & & $(0.090)^{* *}$ \\
\hline \multirow[t]{2}{*}{ SATISFIED WITH COUNTRY } & -0.223 & -0.210 \\
\hline & $(0.098)^{*}$ & $(0.098)^{*}$ \\
\hline \multirow[t]{2}{*}{ INCOME } & -0.054 & -0.072 \\
\hline & $(0.052)$ & $(0.050)$ \\
\hline \multirow[t]{2}{*}{ CELLPHONE OWNER } & -0.086 & -0.046 \\
\hline & (0.119) & (0.119) \\
\hline \multirow[t]{2}{*}{ IMPORTANCE OF RELIGION } & -0.082 & -0.073 \\
\hline & $(0.062)$ & $(0.063)$ \\
\hline \multirow[t]{2}{*}{ INDONESIA } & 1.923 & 2.008 \\
\hline & $(0.214)^{* *}$ & $(0.212)^{* *}$ \\
\hline \multirow[t]{2}{*}{ JAPAN } & 0.880 & 0.924 \\
\hline & $(0.182)^{* *}$ & $(0.183)^{* *}$ \\
\hline \multirow[t]{2}{*}{ SOUTH KOREA } & 0.670 & 0.671 \\
\hline & $(0.176)^{* *}$ & $(0.177)^{* *}$ \\
\hline \multirow[t]{2}{*}{ AGE } & 0.0008 & 0.001 \\
\hline & $(0.004)$ & $(0.004)$ \\
\hline \multirow[t]{2}{*}{ CONSTANT } & 1.201 & 1.457 \\
\hline & $(0.382)^{* *}$ & $(0.373)^{* *}$ \\
\hline \multirow[t]{2}{*}{ CONSTANT } & 3.007 & 3.245 \\
\hline & $(0.387)^{* *}$ & $(0.379)^{* *}$ \\
\hline $\mathbf{N}$ & 2,824 & 2,777 \\
\hline
\end{tabular}

$\mathrm{ID}=$ Indonesia, $\mathrm{JP}=\mathrm{Japan}, \mathrm{KR}=$ Korea, $\mathrm{US}=$ the United States 
Appendix Table III. Explaining Hostility among Women around the Pacific

\begin{tabular}{|c|c|c|c|c|c|c|}
\hline & $\begin{array}{l}\text { MODEL } \\
\text { A9 }\end{array}$ & $\begin{array}{l}\text { MODEL } \\
\text { A10 }\end{array}$ & $\begin{array}{c}\text { MODEL } \\
\text { A11 }\end{array}$ & $\begin{array}{l}\text { MODEL } \\
\text { A12 }\end{array}$ & $\begin{array}{l}\text { MODEL } \\
\text { A13 }\end{array}$ & $\begin{array}{l}\text { MODEL } \\
\text { A14 }\end{array}$ \\
\hline $\begin{array}{r}\text { Dependent Variable: } \\
\text { Countries: }\end{array}$ & \multicolumn{2}{|c|}{$\begin{array}{l}\text { chinaenemy } \\
\text { ID, JP, KR, US }\end{array}$} & \multicolumn{2}{|c|}{$\begin{array}{c}\text { chineseUShostile } \\
\text { RC }\end{array}$} & \multicolumn{2}{|c|}{$\begin{array}{c}\text { chineselndiahostile } \\
\text { RC }\end{array}$} \\
\hline \multirow{2}{*}{$\begin{array}{l}\text { EQUAL RIGHTS FOR } \\
\text { WOMEN }\end{array}$} & -0.178 & & -0.859 & & -1.526 & \\
\hline & $(0.264)$ & & $(0.350)^{*}$ & & $(0.306)^{* *}$ & \\
\hline \multirow{2}{*}{$\begin{array}{l}\text { EQUAL MARRIAGE } \\
\text { BETTER }\end{array}$} & & -0.457 & & -0.582 & & -0.390 \\
\hline & & $(0.155)^{* *}$ & & $(0.203)^{* *}$ & & $(0.210)$ \\
\hline \multirow{2}{*}{$\begin{array}{l}\text { MARKET ECONOMY } \\
\text { BETTER }\end{array}$} & 0.008 & -0.019 & -0.289 & -0.326 & -0.107 & -0.133 \\
\hline & $(0.102)$ & (0.104) & $(0.134)^{*}$ & $(0.135)^{*}$ & $(0.138)$ & (0.139) \\
\hline \multirow[t]{2}{*}{ INTERNET USER } & 0.298 & 0.309 & -0.001 & 0.033 & 0.104 & 0.126 \\
\hline & $(0.212)$ & $(0.215)$ & $(0.217)$ & $(0.218)$ & $(0.215)$ & $(0.215)$ \\
\hline \multirow[t]{2}{*}{ EDUCATION } & -0.220 & -0.227 & 0.036 & 0.055 & -0.209 & -0.192 \\
\hline & (0.139) & $(0.141)$ & $(0.142)$ & $(0.142)$ & $(0.146)$ & $(0.146)$ \\
\hline \multirow{2}{*}{$\begin{array}{l}\text { SATISFIED WITH } \\
\text { COUNTRY }\end{array}$} & -0.243 & -0.234 & -0.443 & -0.347 & -0.559 & -0.490 \\
\hline & $(0.163)$ & $(0.165)$ & $(0.233)$ & $(0.236)$ & $(0.231)^{*}$ & $(0.233)^{*}$ \\
\hline \multirow[t]{2}{*}{ INCOME } & -0.021 & -0.014 & -0.036 & -0.007 & 0.011 & 0.026 \\
\hline & $(0.079)$ & $(0.080)$ & $(0.097)$ & $(0.097)$ & $(0.100)$ & (0.099) \\
\hline \multirow[t]{2}{*}{ CELLPHONE OWNER } & -0.216 & -0.131 & -0.108 & -0.208 & 0.242 & 0.153 \\
\hline & $(0.223)$ & $(0.225)$ & $(0.282)$ & $(0.277)$ & (0.309) & $(0.299)$ \\
\hline \multirow{2}{*}{$\begin{array}{l}\text { IMPORTANCE OF } \\
\text { RELIGION }\end{array}$} & -0.048 & -0.084 & & & & \\
\hline & $(0.078)$ & (0.079) & & & & \\
\hline \multirow[t]{2}{*}{ INDONESIA } & -0.879 & -0.900 & & & & \\
\hline & $(0.286)^{* *}$ & $(0.286)^{* *}$ & & & & \\
\hline \multirow[t]{2}{*}{ JAPAN } & -0.168 & -0.199 & & & & \\
\hline & $(0.244)$ & $(0.249)$ & & & & \\
\hline \multirow{2}{*}{ SOUTH KOREA } & 0.873 & 0.804 & & & & \\
\hline & $(0.194)^{* *}$ & $(0.198)^{* *}$ & & & & \\
\hline \multirow[t]{2}{*}{ CONSTANT } & -0.916 & -0.684 & -0.523 & -0.826 & -0.379 & -1.454 \\
\hline & $(0.482)$ & $(0.444)$ & $(0.516)$ & $(0.435)$ & $(0.510)$ & $(0.459)^{* *}$ \\
\hline$N$ & 1,491 & 1,469 & 1,583 & 1,577 & 1,583 & 1,578 \\
\hline
\end{tabular}

${ }^{*} p<0.05 ;{ }^{* *} p<0.01$

$\mathrm{ID}=$ Indonesia, $\mathrm{JP}=$ Japan, $\mathrm{KR}=$ Korea, US= the United States, $\mathrm{RC}=$ Republic of China 
Appendix Table IV. Explaining Intolerance among Women in Indonesia, Japan, South Korea, and the USA

MODEL A15 MODEL A16

\begin{tabular}{|c|c|c|}
\hline \multirow{2}{*}{$\begin{array}{r}\begin{array}{r}\text { Dependent Variable: } \\
\text { Countries: }\end{array} \\
\text { EQUAL RIGHTS FOR WOMEN }\end{array}$} & \multicolumn{2}{|c|}{$\begin{array}{c}\text { intoleranceJewsChristiansMuslims } \\
\text { ID, JP, KR, US }\end{array}$} \\
\hline & -0.471 & \\
\hline & $(0.175)^{* *}$ & \\
\hline \multirow[t]{2}{*}{ EQUAL MARRIAGE BETTER } & & -0.251 \\
\hline & & $(0.137)$ \\
\hline \multirow[t]{2}{*}{ MARKET ECONOMY BETTER } & -0.216 & -0.247 \\
\hline & $(0.087)^{*}$ & $(0.087)^{* *}$ \\
\hline \multirow[t]{2}{*}{ INTERNET USER } & -0.092 & -0.086 \\
\hline & $(0.212)$ & $(0.212)$ \\
\hline \multirow[t]{2}{*}{ EDUCATION } & -0.034 & -0.022 \\
\hline & $(0.135)$ & $(0.135)$ \\
\hline \multirow[t]{2}{*}{ SATISFIED WITH COUNTRY } & -0.225 & -0.210 \\
\hline & $(0.141)$ & $(0.141)$ \\
\hline \multirow[t]{2}{*}{ INCOME } & -0.133 & -0.152 \\
\hline & (0.074) & $(0.074)^{*}$ \\
\hline \multirow[t]{2}{*}{ CELLPHONE OWNER } & -0.047 & -0.020 \\
\hline & $(0.164)$ & $(0.164)$ \\
\hline \multirow{2}{*}{ IMPORTANCE OF RELIGION } & -0.037 & -0.026 \\
\hline & $(0.096)$ & $(0.096)$ \\
\hline \multirow[t]{2}{*}{ INDONESIA } & 2.180 & 2.232 \\
\hline & $(0.280)^{* *}$ & $(0.277)^{* *}$ \\
\hline \multirow[t]{2}{*}{ JAPAN } & 0.964 & 1.052 \\
\hline & $(0.284)^{* *}$ & $(0.284)^{* *}$ \\
\hline \multirow[t]{2}{*}{ SOUTH KOREA } & 0.754 & 0.771 \\
\hline & $(0.268)^{* *}$ & $(0.268)^{* *}$ \\
\hline \multirow[t]{2}{*}{ CONSTANT } & 1.365 & 1.634 \\
\hline & $(0.475)^{* *}$ & $(0.460)^{* *}$ \\
\hline \multirow[t]{2}{*}{ CONSTANT } & 3.155 & 3.410 \\
\hline & $(0.483)^{* *}$ & $(0.469)^{* *}$ \\
\hline $\mathbf{N}$ & 1,472 & 1,452 \\
\hline
\end{tabular}

$\mathrm{ID}=$ Indonesia, JP=Japan, $\mathrm{KR}=$ Korea, US= the United States 
Appendix Table V. Multilevel Models

\begin{tabular}{|c|c|c|c|c|}
\hline \multirow{3}{*}{$\begin{array}{r}\text { Dependent Variable: } \\
\text { Countries: } \\
\text { Equal Rights for Women }\end{array}$} & Model A18 & Model A19 & Model A20 & Model A21 \\
\hline & \multicolumn{2}{|c|}{$\begin{array}{l}\text { chinaenemy } \\
\text { ID, JP, KR, US }\end{array}$} & \multicolumn{2}{|c|}{$\begin{array}{c}\text { intoleranceJewsChristiansMuslims } \\
\text { ID, JP, KR, US }\end{array}$} \\
\hline & -0.324 & & -0.375 & \\
\hline & $(0.231)$ & & $(0.124)^{* *}$ & \\
\hline \multirow[t]{2}{*}{ Equal Marriage Better } & & -0.433 & & -0.200 \\
\hline & & $(0.105)^{* *}$ & & $(0.096)^{*}$ \\
\hline \multirow{2}{*}{ Market Economy Better } & 0.033 & 0.009 & -0.097 & -0.097 \\
\hline & $(0.068)$ & $(0.068)$ & $(0.061)$ & $(0.061)$ \\
\hline \multirow[t]{2}{*}{ Internet User } & 0.411 & 0.426 & -0.257 & -0.232 \\
\hline & $(0.150)^{* *}$ & $(0.152)^{* *}$ & $(0.140)$ & $(0.140)$ \\
\hline \multirow[t]{2}{*}{ Education } & -0.182 & -0.191 & 0.055 & 0.053 \\
\hline & $(0.094)$ & $(0.095)^{*}$ & $(0.093)$ & $(0.093)$ \\
\hline \multirow[t]{2}{*}{ Female } & -0.137 & -0.139 & -0.262 & -0.269 \\
\hline & $(0.099)$ & $(0.100)$ & $(0.093)^{* *}$ & $(0.092)^{* *}$ \\
\hline \multirow[t]{2}{*}{ Satisfied with Country } & -0.278 & -0.257 & -0.190 & -0.164 \\
\hline & $(0.113)^{*}$ & $(0.115)^{*}$ & $(0.101)$ & (0.101) \\
\hline \multirow[t]{2}{*}{ Income } & 0.057 & 0.062 & -0.032 & -0.050 \\
\hline & $(0.053)$ & $(0.054)$ & $(0.051)$ & $(0.051)$ \\
\hline \multirow[t]{2}{*}{ Cellphone Owner } & -0.224 & -0.153 & -0.091 & -0.048 \\
\hline & $(0.160)$ & $(0.162)$ & $(0.122)$ & $(0.122)$ \\
\hline \multirow[t]{2}{*}{ Importance of Religion } & -0.068 & -0.096 & -0.056 & -0.041 \\
\hline & $(0.054)$ & $(0.055)$ & $(0.061)$ & $(0.062)$ \\
\hline \multirow[t]{2}{*}{ Constant } & -0.787 & -0.727 & -0.303 & -0.559 \\
\hline & $(0.371)^{*}$ & $(0.356)^{*}$ & $(0.433)$ & $(0.441)$ \\
\hline \multirow[t]{2}{*}{ Constant } & -1.324 & -12.037 & -15.649 & -21.728 \\
\hline & $(0.865)$ & $(86,878.189)$ & $(1,607,352.274)$ & $(420,520,147.450)$ \\
\hline \multirow[t]{2}{*}{ Constant } & -0.733 & -0.684 & -0.349 & -0.302 \\
\hline & $(0.440)$ & (0.379) & $(0.366)$ & $(0.365)$ \\
\hline $\mathbf{N}$ & 2,899 & 2,850 & 2,858 & 2,813 \\
\hline
\end{tabular}

$\mathrm{ID}=$ Indonesia, $\mathrm{JP}=\mathrm{Japan}, \mathrm{KR}=$ Korea, US= the United States 